\title{
Modelling the kinetics of Listeria monocytogenes in refrigerated fresh beef under different packaging atmospheres
}

\author{
C. Saraiva ${ }^{\mathrm{a}, ~}{ }^{*}, 1$, M.C. Fontes ${ }^{\mathrm{a}, 1}$, L. Patarata ${ }^{\mathrm{a}, 1}$, C. Martins $^{\mathrm{a}}{ }^{1}$, , V. Cadavez $^{\mathrm{b}}$, \\ U. Gonzales-Barron ${ }^{b}$
}

a School of Agrarian and Veterinary Sciences, DCV, CECAV, Centro de Ciência Animal e Veterinária, Universidade de Trás-os-Montes e Alto Douro, Quinta de Prados, 5000-801, Vila Real, Portugal

b CIMO Mountain Research Centre, School of Agriculture, Polytechnic Institute of Braganza, Campus de Santa Apolónia, Apartado 1172, 5301-854, Bragança, Portugal

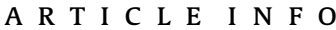

\section{Article history:}

Received 6 June 2015

Received in revised form

6 October 2015

Accepted 17 November 2015

Available online 22 November 2015

\section{Keywords:}

Modified atmosphere packaging (MAP)

Vacuum packaging

Weibull

Survival

Predictive microbiology

\begin{abstract}
A B S T R A C T
The objective of this study was to model the fate of Listeria monocytogenes inoculated in beef at two concentrations (2.5 and $4.0 \mathrm{log} \mathrm{CFU} / \mathrm{g}$ ), packaged under air, vacuum and three modified atmospheres MAP: $70 \% \mathrm{O}_{2} / 20 \% \mathrm{CO}_{2} / 10 \% \mathrm{~N}_{2}, 50 \% \mathrm{O}_{2} / 40 \% \mathrm{CO}_{2} / 10 \% \mathrm{~N}_{2}$ and $30 \% \mathrm{O}_{2} / 60 \% \mathrm{CO}_{2} / 10 \% \mathrm{~N}_{2}$, and refrigerated at a normal temperature $\left(4^{\circ} \mathrm{C}\right)$ and at a mild abusive temperature $\left(9^{\circ} \mathrm{C}\right)$. The experimental design produced a total of 20 environmental conditions. An omnibus model based on the Weibull equation proved statistically that $L$. monocytogenes survives better in vacuum (VP) than in aerobic conditions, although without significant difference in its ability to survive in the temperature range between $4{ }^{\circ} \mathrm{C}$ and $9{ }^{\circ} \mathrm{C}$. Furthermore, regardless of the refrigeration temperature, the presence of $\mathrm{CO}_{2}$ in the package atmosphere exerted a bactericidal effect on $L$. monocytogenes cells, being approximately $1.5 \log$ of reduction when storage time reached 10 days. Since the pathogen can survive in VP/MAP beef, there is a need of maintaining its numbers below $100 \mathrm{CFU} / \mathrm{g}$ before packaging by placing efforts on the implementation of control measures during processing.
\end{abstract}

(๑) 2015 Elsevier Ltd. All rights reserved.

\section{Introduction}

Listeria monocytogenes is a Gram-positive anaerobic facultative food-borne pathogen capable to survive in environments with $\mathrm{pH}$ between 4.0 and 9.6 (optimum 6.0-8.0), and at water activity $\left(\mathrm{a}_{\mathrm{w}}\right)$ levels as low as 0.90 (Farber \& Peterkin, 1991). Moreover, this pathogen can survive at temperatures below freezing, and can grow from $1{ }^{\circ} \mathrm{C}$ to $45^{\circ} \mathrm{C}$. As a consequence, because of this bacterium's ability to proliferate under chilled temperatures, some types of food products have recurrently exhibited more susceptibility to L. monocytogenes contamination. In particular, refrigerated meats, ready-to-eat meat (RTE) foods, milk and cheeses, smoked fish and seafood, have been implicated in isolated cases of listeriosis (EFSA, 2015; Martins \& Germano, 2011). As L. monocytogenes is a microorganism of ubiquitous nature, meat products may become

\footnotetext{
* Corresponding author. Departamento das Ciências Veterinárias, CECAV, Universidade de Trás-os-Montes e Alto Douro, Apartado 1013, 5001-911, Vila Real, Portugal.

E-mail address: crisarai@utad.pt (C. Saraiva).

1 www.utad.pt.
}

contaminated with this pathogen through raw materials, processing environment and at retail markets (Sofos \& Geornaras, 2010).

In 2013, EU reported 1763 confirmed human cases of listeriosis, which represented an $8.6 \%$ increase compared to 2012 . It was also concluded that there was a statistically significant increasing trend of listeriosis in the EU over the period 2009-2013 (EFSA, 2015). A recent meta-analysis on the incidence of pathogens in Portuguese meats revealed that incidence average of $L$. monocytogenes in beef meat is $17.6 \%$, and in meat products is $8.8 \%$ (Xavier, GonzalesBarron, Paula, Estevinho, \& Cadavez, 2014). Although the concentrations are unknown, and may as well be low, these high prevalence estimates may represent a considerable risk due to the common practice among consumers of eating rare meat. Other malpractices resulting in higher $L$. monocytogenes levels, such as cross contamination and storage at abusive temperatures, may also exacerbate the risk for consumers, especially for immunocompromised people (Swaminathan \& Gerner-smidt, 2007). According to Santos, Correia, Cunha, Saraiva, and Novais (2005), the limit of 2.0 $\log$ CFU/g of RTE was considered unacceptable or potentially dangerous for public health. This limit must not be exceeded at the end of the shelf-life (Commission European Communities, 2008). 
Among the parameters affecting the growth of microorganisms in packaged raw meat, it is assumed that the final $\mathrm{pH}$ and the gaseous composition of the packaging have an important role (Zakrys, Hogan, O'Sullivan, Allen, \& Kerry, 2008). In red meat packaging, the most common methods are vacuum packaging (VP) and modified atmosphere packaging (MAP). It is well known that the composition of modified atmosphere systems can be an effective way to restrict the growth of spoilage aerobic organisms (McMillin, 2008; Tsigarida, Skandamis, \& Nychas, 2000); but their effectiveness strongly depends on storage temperature and film permeability (McMillin, 2008). Nevertheless, the extended shelflife of refrigerated meats under VP and MAP conditions has raised concerns about the survival dynamics of $L$. monocytogenes. At present, in the literature, there are a series of contradictions related to the effect of VP and MAP on the growth/survival of this pathogen in meats and meat products (Arvanitoyannis \& Kotsanopoulos, 2012, Chap. 3; Arvanitoyannis \& Stratakos, 2012, Chap. 5; García-deFernando, Nychas, Peck, \& Ordóñez, 1995; Lyver, Smith, Tarte, Farber, \& Nattress, 1998; Uppal et al., 2012). In addition, in the references above, no efforts have been directed to developing a predictive microbiology model that can estimate the dynamics of $L$. monocytogenes in refrigerated packaged meat. Within this context, the objective of this work was to assess, by means of predictive microbiology modelling, the effect of packaging (air, vacuum and three gas compositions of MAP) on the dynamics of $L$. monocytogenes inoculated at low and high level in beef meat stored at a normal refrigeration temperature $\left(4^{\circ} \mathrm{C}\right)$ and a mild abusive temperature $\left(9^{\circ} \mathrm{C}\right)$.

\section{Material and methods}

\subsection{Preparation of meat samples}

Samples of Longissimus dorsi (LD) muscle were obtained from eight Portuguese bulls aged 9-11 months old, having carcass weights between 90 and $150 \mathrm{~kg}$. LD was excised from the carcasses, between the 6 th thoracic and the 2 nd lumbar vertebra $24 \mathrm{~h}$ post mortem. The $\mathrm{pH}$ was measured directly in the muscle using a combined glass electrode with a pH-metre (Crison Instruments, Spain) (ISO 2917, 1999). Only muscles whose pH were below or equal to 5.8 were used. The activity of water $\left(\mathrm{a}_{\mathrm{w}}\right)$ was measured with a rotronic-Hygroskop DT at $25{ }^{\circ} \mathrm{C}$ according to ISO 21807 (2004). The $a_{w}$ of muscles were $0.97 \pm 0.01$. Muscles were cut into pieces of approximately $200 \mathrm{~g}$ and two samples of each piece were immediately ( $24 \mathrm{~h}$ post mortem) investigated for the presence of L. monocytogenes according to ISO 11290-1 (1996). If at least one positive-sample from each muscle were detected in one meat cut, all piece cuts of the whole muscle were totally excluded from the inoculation experiments. Meat cuts were then packed in vacuum, and kept at $-80{ }^{\circ} \mathrm{C}$ during 15 days before the experiment. For the experiments, meat was left to defrost overnight at $2{ }^{\circ} \mathrm{C}$. Meat samples were then prepared by removing a layer of $\sim 1 \mathrm{~cm}$ from the meat surface, and aseptically cut in small meat pieces $(0.5 \mathrm{~cm}$ thick, surface $2 \times 2.5 \mathrm{~cm}$ ) of a weight of $\sim 5 \mathrm{~g}$.

\subsection{Preparation of inoculum and inoculation procedure}

L. monocytogenes (ATCC 7973) stock culture was cultured on tryptone soy agar (TSA, England) slants at $4{ }^{\circ} \mathrm{C}$, which were replaced every 30 days. During the course of the study, this bacteria was sub-cultured by transferring a single colony from the slants into $10 \mathrm{ml}$ Brain Heart Infusion (BHI) broth (Oxoid CM225, England) for $24 \mathrm{~h}$ at $37^{\circ} \mathrm{C}$, followed by a second activation step in BHI $\left(37^{\circ} \mathrm{C}\right.$, $18 \mathrm{~h}$ ) to achieve a viable cell population of $9 \log \mathrm{CFU} / \mathrm{ml}$.

The culture was then transferred to a sterile centrifuge bottle and centrifuged at $10,000 \times \mathrm{g}$ for $10 \mathrm{~min}$ at $4{ }^{\circ} \mathrm{C}$. The supernatant was decanted and the sediment suspended in $0.1 \%$ peptone water (Merck, Germany). The washing step was repeated twice. The suspension of washed cells was diluted in a sterile $0.1 \%$ peptone solution to obtain an optical density of $0.5(600 \mathrm{~nm}, 10 \mathrm{~mm})$. Serial (10-fold) dilutions were performed to yield approximately 2.5 or 4 $\log \mathrm{CFU} / \mathrm{g}$.

On the day of the experiment, each piece of beef was placed into an individual package and inoculated with $20 \mu$ bacterial suspension of $L$. monocytogenes in the sample's centre. The entire procedure was repeated to obtain a low inoculation level (2.5 log CFU/g) and a high inoculation level (4.0 log CFU/g). Each bag of beef was massaged manually and then bags were heat-sealed. Duplicate beef samples $(5 \mathrm{~g})$ inoculated with $20 \mu \mathrm{l}$ of $0.1 \%(\mathrm{w} / \mathrm{v})$ sterile peptone water served as negative controls and the bags were heat-sealed.

To verify the number of viable $L$. monocytogenes in the suspension, each inoculum was enumerated by making appropriate dilutions in peptone water $(0.1 \%, \mathrm{w} / \mathrm{v} ; \mathrm{PW})$ in duplicate, and plating onto TSA plates to obtain the initial population densities. Plates were incubated at $37{ }^{\circ} \mathrm{C}$ for $24 \mathrm{~h}$ before enumeration.

\subsection{Packaging}

Inoculated samples were packed in 5 different packaging types, namely: air (A), vacuum (V) and modified atmosphere packaging $70 \% \mathrm{O}_{2} / 20 \% \mathrm{CO}_{2} / 10 \% \mathrm{~N}_{2}\left(\mathrm{MAP}_{70 / 20}\right), 50 \% \mathrm{O}_{2} / 40 \% \mathrm{CO}_{2} / 10 \% \mathrm{~N}_{2} \quad\left(\mathrm{MAP}_{50}\right.$ 40 ) and $30 \% \mathrm{O}_{2} / 60 \% \mathrm{CO}_{2} / 10 \% \mathrm{~N}_{2}\left(\mathrm{MAP}_{30 / 60}\right)$. For air-packaged samples, meat cuts were accommodated in a tray and overwrapped with polyethylene film, while for vacuum-packaged samples, meat cuts were individually packaged in COMBITHERM bags (WIPAK Walsrode, HAFRI) of $0.09 \mathrm{~mm}$ thickness, oxygen transmission rate (OTR) of $63 \mathrm{~cm}^{3} \mathrm{~m}^{-2} \mathrm{day}^{-1}$ at $23{ }^{\circ} \mathrm{C} / 0 \% \mathrm{RH}$, and water vapour transmission (WVT) of $1 \mathrm{~g} \mathrm{~m}^{-2} \mathrm{day}^{-1}$ at $23^{\circ} \mathrm{C} / 85 \% \mathrm{RH}$. For modifiedatmosphere packaged samples, beet cuts were individually placed in COMBITHERM XX bags (WIPAK Walsrode, HAFRI) of $0.115 \mathrm{~mm}$ thickness, a very low $\mathrm{O}_{2}$-permeable film (OTR of $1 \mathrm{~cm}^{3} \mathrm{~m}^{-2}$ day $^{-1}$ at $23{ }^{\circ} \mathrm{C} / 0 \% \mathrm{RH}$ ) with a WVT of $1 \mathrm{~g} \mathrm{~m}^{-2} \mathrm{day}^{-1}$ at $23{ }^{\circ} \mathrm{C} / 85 \% \mathrm{RH}$. The meat samples were packaged either in modified atmosphere or vacuum using a SAMMIC V-420 SGA machine, with a final gas-tomeat ratio of $\sim 3: 1$. Individual samples were then stored at $4 \pm 0.5^{\circ} \mathrm{C}$ and $9 \pm 0.5^{\circ} \mathrm{C}$, and examined for L. monocytogenes counts (ISO 11290-2, 1998) at days 1 (2 h after packaging), 3, 7, 10, 14, 21 and 28 , depending on the packaging system.

\subsection{Microbiological analysis}

At each time point, two samples were prepared for microbiological analysis. The meat cuts were homogenised with 20-ml sterile buffered peptone water (BPW) in a stomacher (IUL, Barcelona, Spain) during 90 ss at room temperature. Serial decimal dilutions were prepared in BPW, and duplicate $0.1 \mathrm{ml}$ samples were then plated onto Compass L. monocytogenes agar (Biokar BM06508). After incubation at $37^{\circ} \mathrm{C}$ for $48 \mathrm{~h}$, typical colonies were counted and results were expressed as $\log \mathrm{CFU} / \mathrm{g}$.

Serial decimal dilutions of control samples were also prepared in BPW, and duplicate $1 \mathrm{ml}$ samples were plated onto selective CFC (Cetrimide, Fucidin, Cephaloridine) Agar (OXOID CM0559) with CFC selective supplement (OXOID SR0103) for Pseudomonas spp. $\left(25^{\circ} \mathrm{C}\right.$ for $48 \mathrm{~h}, \mathrm{NF}$ V04-503, 1988) and $1 \mathrm{ml}$ samples were plated on double layer on MRS agar (OXOID CM361) for LAB counts $\left(37^{\circ} \mathrm{C}\right.$, 24 h) (NF V04-504, 1998).

The enumeration of Pseudomonas spp. (NF V04-503, 1988) was completed by biochemical test in KLIGLER (OXOID CM0033) and oxidase test. Results were expressed as log CFU/g. In case the microorganism counts were below to the detection limit, the result 
was considered to be zero for statistical purposes.

\subsection{Modelling the survival of L. monocytogenes}

The survival of $L$. monocytogenes in inoculated beef meat of normal $\mathrm{pH}$ was modelled using the Weibull exponential decay function as the primary predictive microbiology model (i.e., a model describing microbial concentration as a function of time). The three-parameter Weibull model is defined as,

$\log N(t)=\log N_{0}-\left(\frac{t}{\chi}\right)^{\beta}$

with $\chi$ representing the scale parameter and $\beta$ the shape parameter. Although the Weibull model is basically of empirical nature, Van Boekel (2002) suggested that $\beta<1$ (i.e., concave curves) presumes that the surviving microorganisms have the capacity to adapt to the applied stress, whereas $\beta>1$ (convex curves) indicates that the remaining cells become increasingly susceptible to heat. The dependent variable $\log \mathrm{N}(\mathrm{t})$ used is the logarithm base $10(\log )$ of the number of cells at time $t$. Log $\mathrm{N}_{\text {res }}$ is the residual log number of microorganisms, which is in fact a parameter associated with the tailing effect, and $\log \mathrm{N}_{0}$ is the initial logarithmic number of microorganisms. Log $\mathrm{N}_{0}$ was considered to be a model parameter and not the first observation when $t=0$ as it is preferable for a kinetics model to describe the absolute population and not the population relative to the initial population (Geeraerd, Herremans, \& Van Impe, 2000).

The experimental design of the survival study was of the type $2^{2} \times 5^{1}$ for two factors (inoculation level and storage temperature) consisting of two levels each, and one factor (packaging) consisting of five levels. This produced a total of 20 conditions or treatments which were replicated twice (i.e., yielding 40 survival curves). Hence, since the survival experiments were conducted under three different factors, secondary models were developed in order to assess the effects of each of those factors on the primary model's parameters $\left(\chi, \beta\right.$ and $\log \mathrm{N}_{0}$ ). A more informative and neat way to adjust the primary and secondary models is by means of an omnibus or global model (Juneja, Gonzales-Barron, Butler, Yadav, \& Friedman, 2013; Pradhan et al., 2012), which is a type of model fitting that jointly estimates the parameters of the primary and secondary models using all the experimental curves. Thus, the omnibus model based on the Weibull equation assumed that its parameters $\left(\chi, \beta\right.$ and $\left.\log N_{0}\right)$ could be expressed as a function of the three following categorical variables: (i) the factor packaging type defined as "Pack" comprising five levels: air (A), vacuum $(\mathrm{V})$ and modified atmosphere packaging $\mathrm{MAP}_{70 / 20}, \mathrm{MAP}_{50 / 40}$ and $\mathrm{MAP}_{30 / 60}$; (ii) the factor inoculation level "Inoc" consisting of a high level (4.0 $\log \mathrm{CFU} / \mathrm{g}$ ) and a low level (2.5 log CFU/g), and (iii) the storage temperature "T" encompassing an optimal refrigeration temperature $\left(4^{\circ} \mathrm{C}\right)$ and a temperature of mild abuse $\left(9^{\circ} \mathrm{C}\right)$.

The concentration $\log \mathrm{N}_{\mathrm{ijk}}$ of $L$. monocytogenes in beef with the level of inoculum $i$, packaged under the gaseous composition $j$ and stored at the refrigeration temperature $k$ was estimated as,

$$
\begin{aligned}
& \log N_{i j k}=\log N_{0 i}-\left(\frac{t}{\chi_{j k}}\right)^{\beta_{j}}+\varepsilon_{i j k} \\
& \operatorname{Ln}_{j k}=a_{1} \operatorname{Pack}_{j}+a_{2} T_{k} \\
& \operatorname{Ln} \beta_{j}=\operatorname{bPack}_{j} \\
& \log _{0_{i}}=\operatorname{CInoc}_{i}
\end{aligned}
$$

where $\varepsilon_{\mathrm{ijk}}$ are the residuals which are assumed to follow a normal distribution with mean zero and standard deviation $\sigma$. The factor
"Inoc" was removed as a predictor of $\operatorname{Ln} \chi$ and $\operatorname{Ln} \beta$ as it did not have any significant effect. Similarly, the temperature "T" did not significantly affect $\operatorname{Ln} \beta$. However, the initial microbial concentration (parameter $\log \mathrm{N}_{0}$ ) could only be modelled as a function of the level of inoculum "Inoc", and hence neither "Pack" nor "T" was placed in the equation of $\log \mathrm{N}_{0}$. The factors "Inoc", "Pack" and "T" predicting the Weibull model's parameters were added to the omnibus model one by one while assessing the improvement in the goodness-of-fit measures (log-likelihood, Akaike Information Criterion $[\mathrm{AIC}]$ and $\mathrm{BIC}$ ) and the behaviour of the residuals. The model was adjusted in $\mathrm{R}$ version 2.14.2 ( $\mathrm{R}$ Development Core Team) using the "nlme" package and the "glns" function.

\section{Results and discussion}

The survival studies showed overall that the population numbers of $L$. monocytogenes decreased during storage of raw beef at refrigeration temperature (Fig. 1), suggesting that the packaging environment, product characteristics and, eventually, interactions with other competitive microbiota were not favourable for the growth of this pathogen. The Weibull model was able to closely represent the experimental survival curves of inoculated L. monocytogenes in beef for each of the twenty environmental conditions. The omnibus regression evidenced that the level of inoculum did not affect the parameter values of the Weibull model (viz. notice the absence of "Inoc" as predictor of $\chi$ or $\beta$ in Table 1 ), meaning that, regardless of the level of inoculation, the shape of the survivors' curve remains with the same tendency. Mathematically, this implies that, keeping $\chi$ and $\beta$ constant, a lower or higher level of contamination will merely shift the survival curve down- or upwards, respectively (Notice in Fig. 1 that for a fixed packaging condition and temperature, the increase or decrease in the level of inoculum does not affect the shape of the fitted curve). Biologically, this may indicate that, within such low levels of inoculum (2.5-4.0 $\log$ CFU/g), there is no appreciable change in the possible effect of other meat microbiota on the dynamics of $L$. monocytogenes. For example, it could have been argued that, at a lower pathogen's population, the survival or death rate becomes faster prompted by the predominance of other microbiota in proportionally higher numbers (Fig. 3). However, seemingly this did not occur as there was no significant change in the shape of the survivors' curves between the two inoculum levels. Conversely, as expected, the level of inoculum determined $(\mathrm{P}<.0001)$ the value of the fitted initial microbial concentration ( $\log \mathrm{N}_{0}$ ) of a survival curve. The estimated means of $\log \mathrm{N}_{0}$ for the high (4.045; Table 1) and low (2.560) inoculum corresponded closely to the target concentrations of L. monocytogenes inoculated ( 4.0 and $2.5 \mathrm{log} \mathrm{CFU} / \mathrm{g})$ in the experiments.

With regards to the scale parameter $\chi$, both storage temperature and packaging type influenced its value (Table 1 ). Since the scale parameter $\chi$ can be interpreted as the time to attain the first decimal reduction (Van Boekel, 2002) a lower intercept estimate of the packaging type will lead to a lower $\operatorname{Ln} \chi$ (Eq. (2)); suggesting hence a greater microbial inhibition for the same storage time. The omnibus model inferred that the survival of $L$. monocytogenes in vacuum packaging (Pack.V intercept of 2.625 in Table 1) was significantly better than in aerobic conditions (Pack.A $=2.142$ ). In other words, oxygen restriction via vacuum showed consistently less reduction in inoculated $L$. monocytogenes populations than air packaging (Fig. 2). Comparable findings were reported by Uppal et al. (2012), who observed that VP treatment was less effective in reducing $L$. monocytogenes in turkey tenders. It is not surprising that, because of its facultative anaerobic character, L. monocytogenes in vacuum may behave more competitively than other microbiota, as earlier suggested by Duffy, Vanderlinde, and 


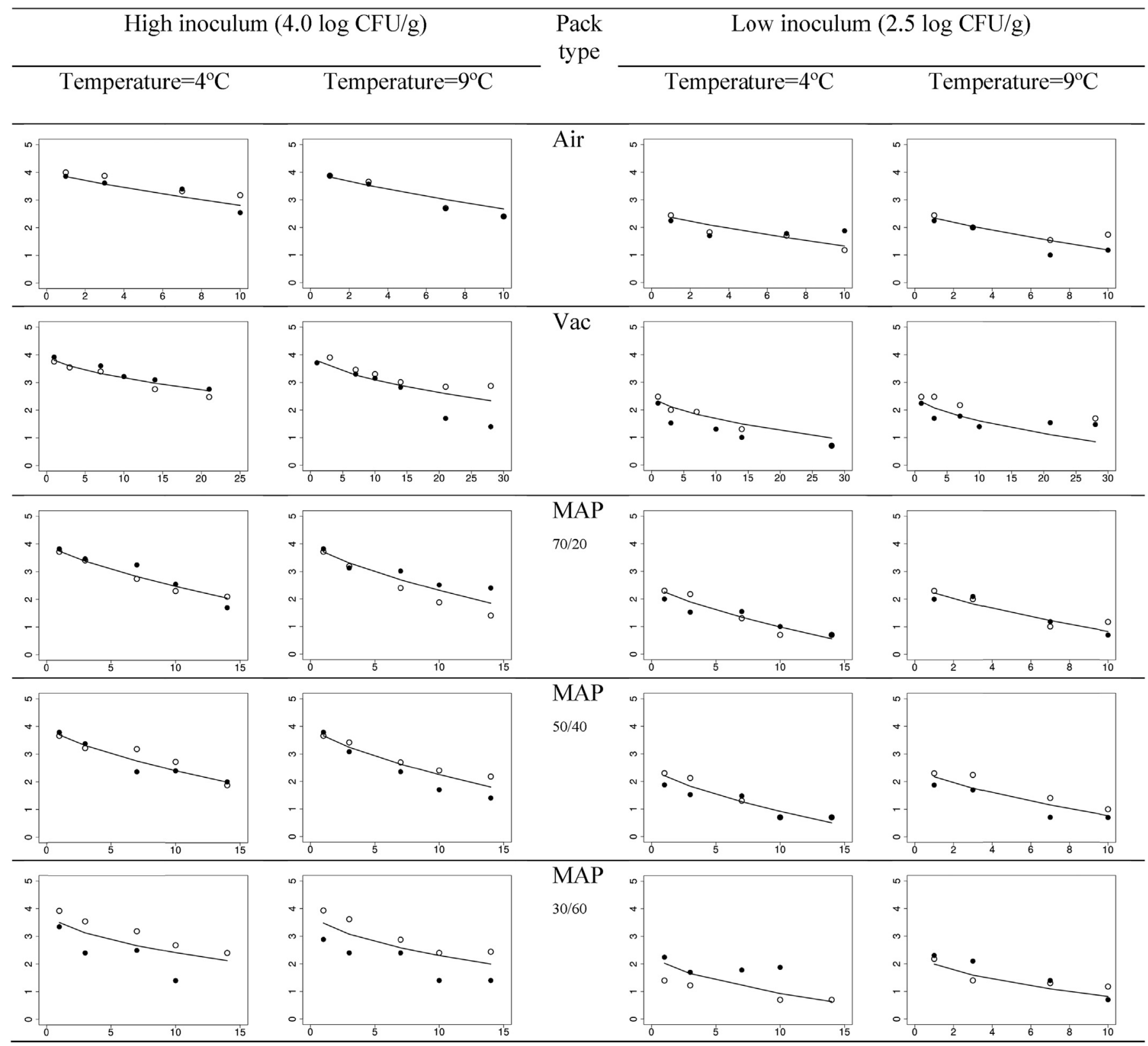

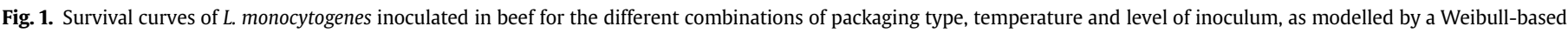

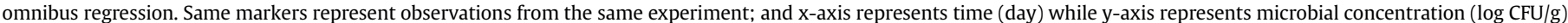
( ${ }^{\circ}$ experiment $1 ; \bullet$ experiment 2 ).

Grau (1994). Indeed, in VP, there is a shift from Gram-negative aerobic microbiota towards Gram-positive bacteria (Nychas, Drosinos, \& Board, 1998). Specific spoilage bacteria have in air packaging better environmental conditions with the usual production of metabolites that hinders the ability of $L$. monocytogenes to survive. This may explain, to some extent, why L. monocytogenes populations decreased in air-packaged meat. However, results of Tsigarida et al. (2000) demonstrated that under aerobic conditions, pseudomonads in refrigerated beef predominated by yielding maximum levels of $10 \log \mathrm{CFU} / \mathrm{g}$, while $L$. monocytogenes had a slight growth. In our study, the greater survival of this pathogen in vacuum than in air-packaged samples may be also related to the $\mathrm{O}_{2}$ permeability of the packaging film used for VP (OTR $=63.0$ $\mathrm{cm}^{3} \mathrm{~m}^{2} \mathrm{day}^{-1}$ ), which may not inhibit the $L$. monocytogenes development so efficiently, and the very low concentration of $\mathrm{CO}_{2}$ in VP which renders a more favourable condition for the pathogen's survival. The effective inhibition of $L$. monocytogenes in raw meats by $\mathrm{CO}_{2}$ has been pointed out by several authors (Bennik, Smid, Rombouts, \& Gorris, 1995; Fraqueza, Ferreira, \& Barreto, 2006; Nissen, Alvseike, Bredholt, Holck, \& Nesbakken, 2000; Stanbridge \& Davies, 1998).

To this respect, the omnibus regression model confirmed that the reduction of L. monocytogenes in any of the MAP treatments was significantly greater than in the air-packaged meat samples (Fig. 2). Furthermore, the intercept estimates for $\mathrm{MAP}_{70 / 20}$ (1.771; Table 1), $\mathrm{MAP}_{50 / 40}$ (1.666) and $\mathrm{MAP}_{30 / 60}$ (1.395) decreased progressively because a higher $\mathrm{CO}_{2}$ concentration had a greater effect on decreasing the $L$. monocytogenes population in packaged raw beef (Fig. 2); and this occurred regardless of the refrigeration temperature evaluated. This can also be associated to the resistance of LAB 


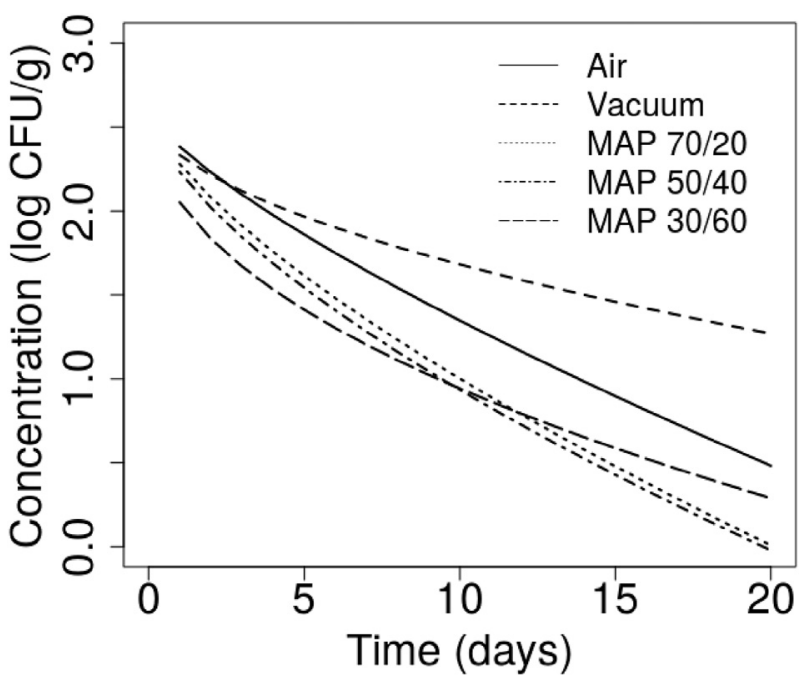

Fig. 2. Fitted survival curves of low-inoculum L. monocytogenes in beef under different packaging systems stored at $4{ }^{\circ} \mathrm{C}$.

\section{Table 1}

Parameter estimates of the omnibus model based on the Weibull exponential function predicting the non-log-linear decline of L. monocytogenes in inoculated beef meat as a function of packaging type (Pack), storage temperature (T) and level of inoculum (Inoc).

\begin{tabular}{|c|c|c|c|c|}
\hline Parameters & Mean* & Standard error & $\operatorname{Pr}>|t|$ & AIC/BIC \\
\hline \multicolumn{5}{|l|}{ Predictors of $\operatorname{Ln} \chi$} \\
\hline $\mathrm{T}$ & -0.026 & 0.013 & 0.053 & $118 / 166$ \\
\hline Pack.A & $2.142^{\mathrm{b}}$ & 0.235 & $<0.0001$ & \\
\hline Pack.V & $2.625^{\mathrm{a}}$ & 0.324 & 0.0001 & \\
\hline Pack. $\mathrm{MAP}_{70 / 20}$ & $1.771^{\mathrm{c}}$ & 0.267 & $<0.0001$ & \\
\hline Pack. $\mathrm{MAP}_{50 / 40}$ & $1.666^{\mathrm{cd}}$ & 0.278 & $<0.0001$ & \\
\hline Pack. $\mathrm{MAP}_{30 / 60}$ & $1.395^{\mathrm{d}}$ & 0.356 & 0.0001 & \\
\hline \multicolumn{5}{|l|}{ Predictors of $\operatorname{Ln} \beta$} \\
\hline Pack.A & $-0.222^{\mathrm{c}}$ & 0.303 & 0.465 & \\
\hline Pack.V & $-0.569^{\mathrm{ab}}$ & 0.240 & 0.019 & \\
\hline Pack. $\mathrm{MAP}_{70 / 20}$ & $-0.338^{\mathrm{c}}$ & 0.195 & 0.085 & \\
\hline Pack. $\mathrm{MAP}_{50 / 40}$ & $-0.401^{b}$ & 0.185 & 0.032 & \\
\hline Pack. $\mathrm{MAP}_{30 / 60}$ & $-0.724^{\mathrm{a}}$ & 0.182 & 0.0001 & \\
\hline \multicolumn{5}{|l|}{ Predictors of $\log N_{O}$} \\
\hline Inoc.High $(\log \mathrm{CFU} / \mathrm{g})$ & $4.045^{\mathrm{a}}$ & 0.145 & $<0.0001$ & \\
\hline Inoc.Low $(\log C F U / g)$ & $2.560^{\mathrm{b}}$ & 0.146 & $<0.0001$ & \\
\hline \multicolumn{5}{|l|}{ Residuals } \\
\hline$\sigma(\log \mathrm{CFU} / \mathrm{g})$ & 0.234 & & & \\
\hline
\end{tabular}

*Within each Weibull parameter, different superscript letters indicate significant differences $(\mathrm{P}<.05)$.

to $\mathrm{CO}_{2}$ effect (Fig. 3), with the eventual production of substances with inhibitory effect against to L. monocytogenes. Earlier, Nissen et al. (2000) observed that for very high $\mathrm{CO}_{2}$ concentrations (60\%), the development of $L$. monocytogenes in MAP beef was inhibited at $4{ }^{\circ} \mathrm{C}$, while Fraqueza et al. (2006) obtained similar results when they packaged turkey meat in both modified atmospheres $50 \% \mathrm{CO}_{2} / 50 \% \mathrm{~N}_{2}$ and $50 \% \mathrm{CO}_{2} / 50 \%$ Air, and stored it at both $0^{\circ}$ and $7{ }^{\circ} \mathrm{C}$. According to Phillips (1996) storing bovine meat of normal $\mathrm{pH}$ in a $\mathrm{CO}_{2}$ atmosphere efficiently inhibits L. monocytogenes. Even with a brief exposition of the fresh meat of $3 \mathrm{~h}$ to the gas, he verified a delay of the lag-phase for longer than 74 h Bennik, Smid, and Rombouts (1995) explained that, when L. monocytogenes is exposed to high concentrations of $\mathrm{CO}_{2}$, inhibition takes place because of two mechanisms: acidification of the food matrix and a direct inhibitory effect. Diffusion of $\mathrm{H}_{2} \mathrm{CO}_{3}$ through the bacterial cell membrane causes alterations in the intracellular $\mathrm{pH}$, affecting enzymatic activity. High concentrations of $\mathrm{CO}_{2}$ can inhibit the decarboxylation reactions by which $\mathrm{CO}_{2}$ is released through feedback mechanisms. The $\mathrm{CO}_{2}$ effect on Pseudomonas spp. growth is no effective at higher temperature $\left(9^{\circ} \mathrm{C}\right)$ as can be observed in Fig. 3.

The first decimal reduction time $\chi$ was not only affected by the packaging type $(\mathrm{P}<.0001)$ but also by the storage temperature, although to a lesser extent as attested by its higher P-value $(0.053$ in Table 1). The influence of temperature on the kinetics of L. monocytogenes may have not been as high as that of the gaseous atmosphere because the temperature range tested was small (from $4^{\circ}$ to $9^{\circ} \mathrm{C}$ ), and at such interval the pathogen may equally survive with only a slight variation in its dynamics. Notice in Fig. 1, that for a fixed inoculum level and packaging type, the effect of the temperature in the curve decay is weak, and this is reflected on the very low estimate of the temperature effect $(-0.026$ in Table 1$)$. The negative value of the estimate only reflects the inverse relationship; this is, the higher the temperature, the lower the first decimal reduction time (i.e., the higher the survival of the pathogen).

The intercept estimates predicting $\operatorname{Ln} \beta$ (the shape factor) for all packaging types were negative (Table 1 ) because the shape of the survival curves were in all cases concave. The concavity or phenomenon of tailing arises as a manifestation of the natural adaptation of the bacteria to the stress-causing factor(s); in this case, low temperatures, gaseous atmospheres and competitive microbiota. It is known that, in a Weibull decay model depicting concavity, the parameters $\chi$ and $\beta$ are normally correlated (i.e., a lower $\chi$ is associated to a lower $\beta$ ). This happens because when inactivation occurs at a quicker pace, the first decimal reduction time $\chi$ (which can be understood as the inverse of the slope) becomes lower, and at the same time, the curve acquires a greater concavity (i.e., a lower $\beta$ ). Hence, as occurred for the intercept estimates of the packaging types predicting $\operatorname{Ln} \chi$, the intercept estimates for $\mathrm{MAP}_{70 /}$ 20 (-0.338; Table 1), $\mathrm{MAP}_{50 / 40}(-0.401)$ and $\mathrm{MAP}_{30 / 60}(-0.724)$ predicting $\operatorname{Ln} \beta$ also decreased in the same order due to the greater inhibitory effect from increasing the $\mathrm{CO}_{2}$ concentration. Yet, at a storage time of 10 days, a higher proportion of $\mathrm{CO}_{2}$ in the package from $40 \%$ in $\mathrm{MAP}_{50 / 40}$ to $60 \%$ in $\mathrm{MAP}_{30 / 60}$ - provided the same level of reduction in $L$. monocytogenes of $\sim 1.5 \log \mathrm{CFU} / \mathrm{g}$ (Fig. 2).

The dynamics of $L$. monocytogenes in packaged raw meats has been the subject of numerous studies with controversial findings related to the inhibitory effect of VP/MAP. It has been said that this pathogen can still grow in VP/MAP at refrigeration temperatures (Barakat \& Harris, 1999; Sheridan et al., 1995; Tsigarida et al., 2000), while other studies concluded that $L$. monocytogenes can effectively be inhibited by VP/MAP (Fraqueza et al., 2006; Hudson, Mott, \& Penney, 1994). However, it is not unexpected that, in some instances, the outcomes and conclusions from the different studies be barely comparable among themselves; given the many factors creating a unique ecosystem that affect the dynamics of L. monocytogenes in packaged meat. Among other factors, the effectiveness of the packaging systems to inhibit $L$. monocytogenes would strongly depend upon pathogen's strain and physiological status, storage temperature, temperature fluctuations, meat composition and $\mathrm{pH}$, atmosphere composition and $\mathrm{O}_{2} / \mathrm{CO}_{2}$ ratio, packaging film properties such as thickness and permeability, meat-to-air volume ratio within the package, initial concentrations of the microbiota, interrelationships with other bacterial groups such as pseudomonad and lactic acid bacteria, competition and effects of their metabolic end-products.

Thus, while other researchers reported inhibition in the sense of absence of growth of $L$. monocytogenes in refrigerated meat packaged in VP/MAP (Mano et al., 1995; Sheridan et al., 1995; Tsigarida et al., 2000), in this work, there was a decrease in L. monocytogenes numbers during refrigerated storage. For instance, after 10 days of storage at $4{ }^{\circ} \mathrm{C}$, initial populations of $2.5 \log \mathrm{CFU} / \mathrm{g}$ of 

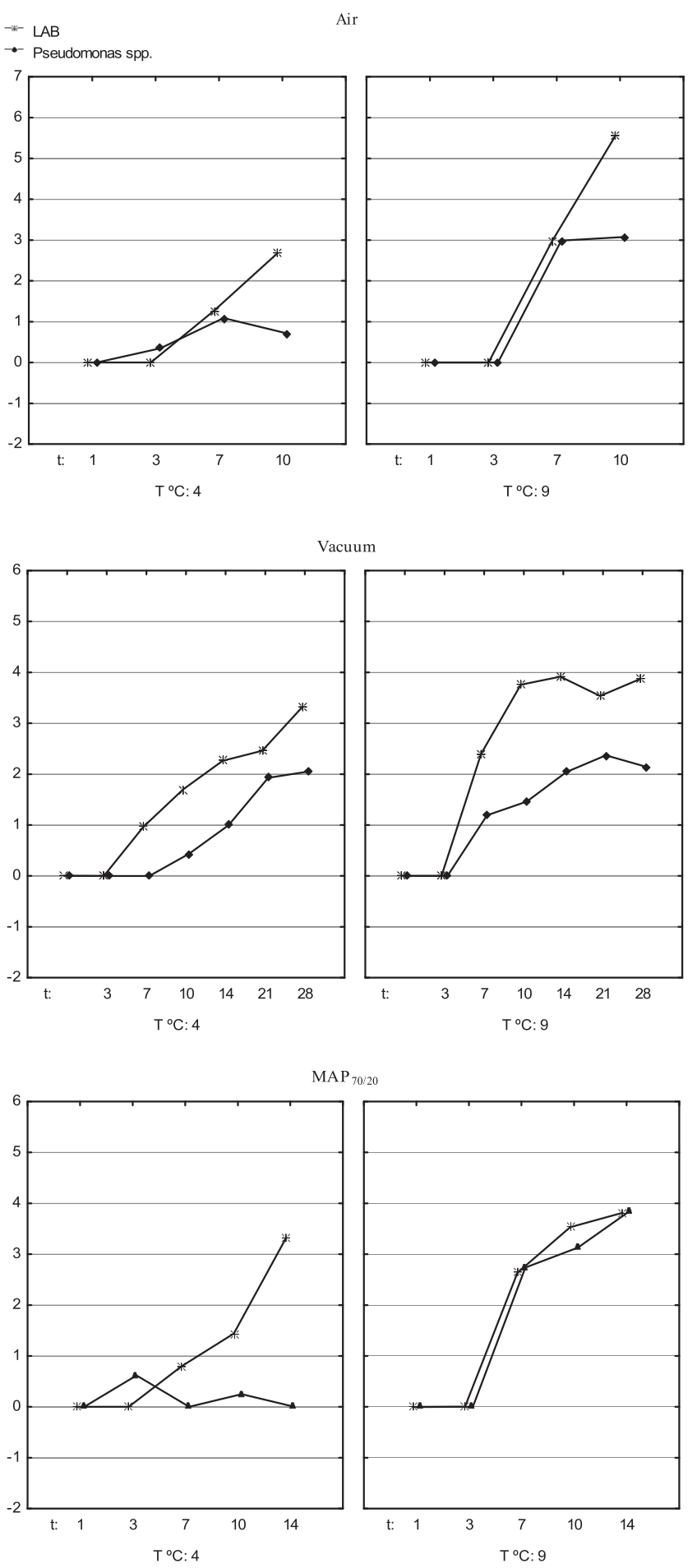

Fig. 3. Microbial evolution of spoilage microorganisms in beef for the different combinations of packaging type and temperature. X-axis represents time (day) while y-axis represents microbial concentration in average (log CFU/g) of Lactic Acid Bacteria (LAB) and Pseudomonas spp..

L. monocytogenes in beef may be reduced by $\sim 1.0 \mathrm{log}$ in vacuum packaging and by $\sim 1.5 \log$ on average in the MAPs (Fig. 2). One of the factors that may have contributed to the progressive reduction of $L$. monocytogenes in MAP, as opposed to the absence of growth previously reported (Sheridan et al., 1995; Tsigarida et al., 2000) may have been the lower oxygen transmission rate $(\mathrm{OTR}=1.0$ $\mathrm{cm}^{3} \mathrm{~m}^{2} \mathrm{day}^{-1}$ ) of the packaging film used in this work for MAP, in
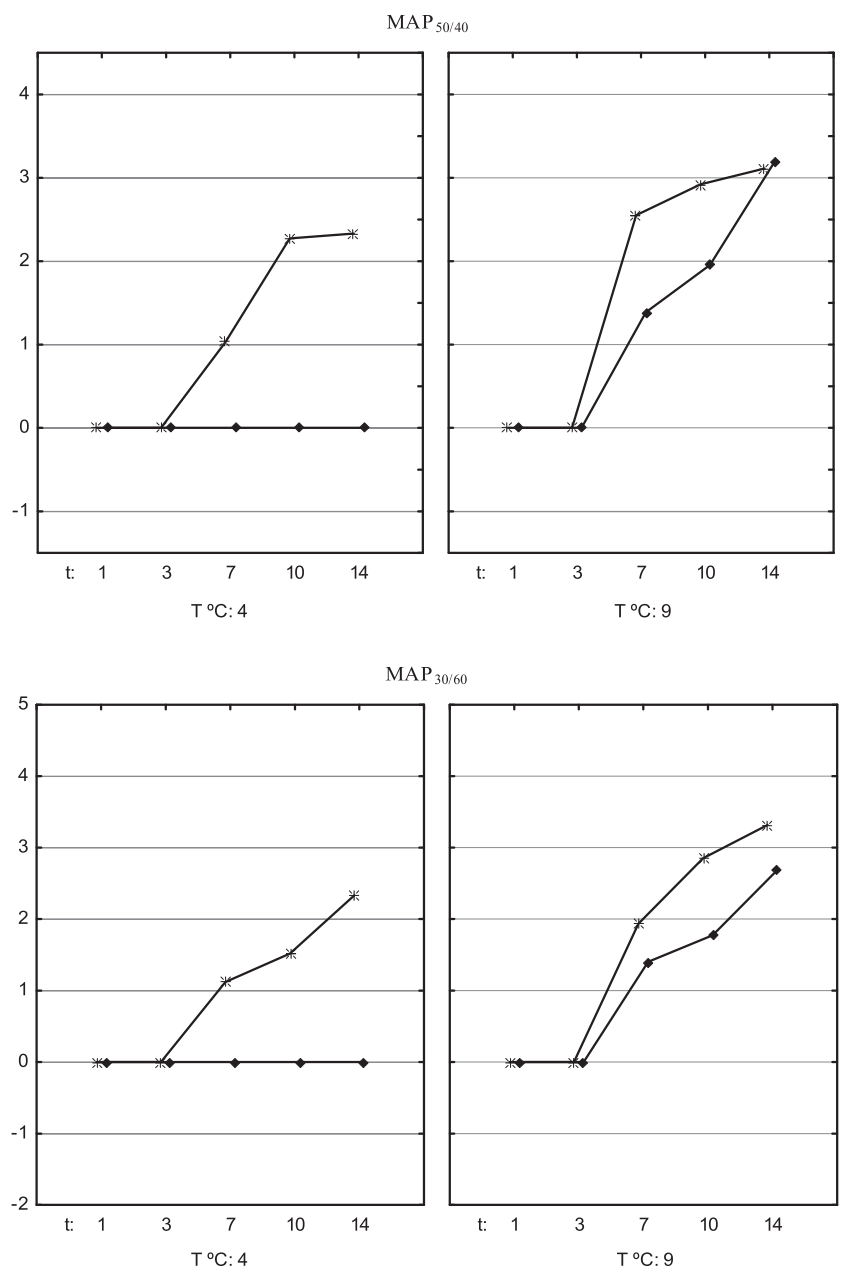

Fig. 3. (continued)

comparison to the films of greater $\mathrm{O}_{2}$ permeability used in the studies mentioned above. Specifically, using a MAP film of OTR $=4.5 \mathrm{~cm}^{3} \mathrm{~m}^{2} \mathrm{day}^{-1}$, Tsigarida et al. (2000) found no growth in refrigerated meat samples stored in $30 \% \mathrm{O}_{2} / 40 \% \mathrm{CO}_{2}$ gaseous atmosphere. Interestingly, when they packaged meat in high permeability films, growth of this pathogen was verified either under VP or MAP. Similarly, Stanbridge and Davies (1998) found no growth of $L$. monocytogenes in refrigerated MAP lamb, using a film whose OTR $\left(8.0 \mathrm{~cm}^{3} \mathrm{~m}^{2} \mathrm{day}^{-1}\right)$ was higher than the one employed in this work. In packaging films with greater $\mathrm{O}_{2}$ permeability, the composition of the gaseous atmospheres within VP/MAP changes dramatically, enhancing the growth of pseudomonas, and as a consequence, stimulation of $L$. monocytogenes can occur. On the contrary, the use of low $\mathrm{O}_{2}$ permeability films regulates the inhibition of $L$. monocytogenes throughout the storage period (Tsigarida et al., 2000). Furthermore, our results are in agreement to those of Fraqueza et al. (2006) who verified a slight decrease in L. monocytogenes inoculated in raw turkey meat when packaged also in low $\mathrm{O}_{2}$-permeability film under MAP $50 \% \mathrm{~N}_{2} / 50 \% \mathrm{CO}_{2}$ and stored at $0{ }^{\circ} \mathrm{C}$. In this particular work, other factors that may have contributed to the decrease in $L$. monocytogenes observed in VP/ MAP could have been the high gas-to-meat ratio (3:1) for the small meat sample used in the package $(\sim 5 \mathrm{~g})$. Generally, under anaerobic MAP, lactic acid bacteria have shown to be effective in inhibiting the growth of pathogenic bacteria such as L. monocytogenes in meat (Phillips, 1996). Nychas et al. (1998) showed that the availability of 
ecological determinants $\left(\mathrm{O}_{2}\right.$ tension, type of available substrates and temperature) strongly affects the end-products formation by lactic acid bacteria and Brochothrix thermosphacta. Bacteriocins, $\mathrm{H}_{2} \mathrm{O}_{2}$, lactate, acetate and formate are among these products, which could also contribute further to the reduction in L. monocytogenes numbers in VP/MAP beef. Finally, the omnibus model based on the Weibull decay function is a working model that can be used to estimate the decrease in the counts of $L$. monocytogenes in beef meat packaged in VP/MAP at any time point during refrigerated storage at $4^{\circ}$ and $9{ }^{\circ} \mathrm{C}$.

\section{Conclusions}

The omnibus regression model proved that vacuum packaging was significantly less efficient than MAP in reducing L. monocytogenes numbers in raw beef, while higher $\mathrm{CO}_{2}$ concentrations in MAP exerted a greater bactericidal effect regardless of the refrigeration temperature, with $\mathrm{MAP}_{50 / 40}$ being as effective as $\mathrm{MAP}_{30 / 60}$ when storage time reached 10 days ( 1.5 log reduction). Yet, the effect of the temperature $(\mathrm{P}=.05)$ on $L$. monocytogenes inhibition was lower than the effect of the gaseous atmosphere $(\mathrm{P}<.0001)$, implying that there is little difference in the ability of L. monocytogenes to survive either at $4{ }^{\circ} \mathrm{C}$ or at $9{ }^{\circ} \mathrm{C}$. The pathogen survived significantly better in vacuum than in aerobic conditions, which can be due to its facultative anaerobic nature, and to the better development of spoilage bacteria in air packaging. Because vacuum and MAP systems may at most reduce the numbers of L. monocytogenes by $\sim 1.0$ and $\sim 1.5 \mathrm{log}$, respectively, after 10 days of refrigerated storage, they cannot be regarded as a sole hurdle for pathogen reduction, but instead strict control measures should be placed during beef processing stages. Nonetheless, to attain greater inhibition and reduction of $L$. monocytogenes at the packaging stage, the use of microbial- or plant-based antimicrobial substances should be considered as combined hurdles of VP/MAP.

\section{Conflict of interest}

The authors declare no conflict of interest.

\section{Acknowledgements}

The authors would like to thank CECAV-UTAD and the research is supported by national funds by FCT- Portuguese Foundation for Science and Technology, under the PEst-OE/AGR/UI0772/2014. Dr. Gonzales-Barron wishes to acknowledge the financial support provided by the Portuguese Foundation for Science and Technology (FCT) through the award of a five-year Investigator Fellowship (IF) in the mode of Development Grants (IF/00570).

\section{References}

Arvanitoyannis, I. S., \& Kotsanopoulos, K. (2012). Safety and quality control of MAP products. In I. S. Arvanitoyannis (Ed.), Modified atmosphere and active packaging technologies (pp. 61-78). USA: CRC Press, Taylor and Francis GROUP.

Arvanitoyannis, I. S., \& Stratakos. (2012). A. Ch..Fresh and processed meat and meat products. In I. S. Arvanitoyannis (Ed.), Modified atmosphere and active packaging technologies (pp. 223-224). USA: CRC Press, Taylor and Francis Group.

Barakat, R. K., \& Harris, L. J. (1999). Growth of Listeria monocytogenes and Yersinia enterocolitica on cooked modified-atmosphere poultry in the presence and absence of a naturally occurring microbiota. Applied and Environmental Microbiology, 65, 342-345.

Bennik, M. H. J., Smid, E. J., Rombouts, F. M., \& Gorris, L. G. M. (1995). Growth of psychrotrophic foodborne pathogens in a solid surface model system under the influence of carbon dioxide and oxygen. Food Microbiology, 12, 509-519.

Commission of the European Communities. (2008). Commission staff working document. Guidance document SANCO/1628/2008.

Duffy, L. L., Vanderlinde, P. B., \& Grau, F. H. (1994). Growth of Listeria monocytogenes on vacuum-packed cooked meats: effects of pH, aw, nitrite and ascorbate. International Journal of Food Microbiology, 23, 377-390.
European Food Safety Authority (EFSA). (2015). The European Union summary report on trends and sources of zoonoses, zoonotic agents and foodborne outbreaks in 2013. EFSA Journal, 13(1), 3991.

Farber, J. M., \& Peterkin, P. I. (1991). Listeria monocytogenes, a food-borne pathogen. Microbiological Reviews, 55, 476-511.

Fraqueza, M. J., Ferreira, M. C., \& Barreto, A. S. (2006). Listeria monocytogenes in turkey meat under modified atmosphere packaging with gas mixtures of argon or carbon monoxide. Revista Portuguesa de Zootecnia, 13, 19-35.

García-de-Fernando, G. D., Nychas, G. J. E. Peck, M. W., \& Ordóñez, J. A. (1995). Growth/Survival of psychrotrophic pathogens on meat packaged under modified atmospheres. International Journal of Food Microbiology, 28, 221-231.

Geeraerd, A. H., Herremans, C. H., \& Van Impe, J. F. (2000). Structural model requirements to describe microbial inactivation during a mild heat treatment. International Journal of Food Microbiology, 59, 185-209.

Hudson, J. A., Mott, S. J., \& Penney, N. (1994). Growth of Listeria monocytogenes, Aeromonas hydrophila and Yersinia enterocolitica on vacuum and saturated carbon dioxide controlled atmosphere-packaged sliced roast beef. Journal of Food Protection, 57, 204-208.

ISO 11290-1. (1996). Microbiology of food and animal feeding stuffs-horizontal method for the detection and enumeration of Listeria monocytogenes - Part 1 : Detection method. Geneva: International Organization for Standardization.

ISO 11290-2. (1998). Microbiology of food and animal feeding stuffs-horizontal method for the detection and enumeration of Listeria monocytogenes - Part 2: Enumeration method. Geneva: International Organization for Standardization.

ISO 21807. (2004). International Organization for Standardization (2004). Microbiology of food and animal feeding stuffs - Determination of water activity.

ISO 2917. (1999). International Organization for Standardization (2004). Meat and meat products - Measurement of $\mathrm{pH}$ - Reference method.

Juneja, V. K., Gonzales-Barron, U., Butler, F., Yadav, A., \& Friedman, M. (2013). Predictive thermal inactivation model for the combined effect of temperature, cinnamaldehyde and carvacrol on starvation-stressed multiple Salmonella serotypes in ground chicken. International Journal of Food Microbiology, 165 184-199.

Lyver, A., Smith, J. P., Tarte, I., Farber, J. M., \& Nattress, F. N. (1998). Challenge studies with Listeria monocytogenes in a value-added seafood product stored under modified atmospheres. Food Microbiology, 15, 379-389.

Mano, S. B., García de Fernando, G. D., López, D. Selgas, M. D., García, M. L. Cambero, M. I., et al. (1995). Growth/survival of natural flora and Listeria monocytogenes on refrigerated uncooked pork and turkey packaged under modified atmospheres. Journal of Food Safety, 15, 305-319.

Martins, E. A. \& Germano, P. M. L. (2011). Listeria monocytogenes in ready-to-eat, sliced, cooked ham and salami products, marketed in the city of São Paulo, Brazil: occurrence, quantification and serotyping. Food Control, 22, 297-302.

McMillin, K. W. (2008). Where is MAP Going? a review and future potential of modified atmosphere packaging for meat. Meat Science, 80, 43-65.

NF V04-503 (AFNOR). (1988). Viandes et produits à base des viande Dénombrement des Bactéries lactiques.

NF V04-504 (AFNOR). (1998). Viandes et produits à base des viande Dénombrement de Pseudomonas spp..

Nissen, H., Alvseike, O., Bredholt, S., Holck, A., \& Nesbakken, T. (2000). Comparison between the growth of Yersinia enterocolitica, Listeria monocytogenes, Escherichia coli 0157:H7 and Salmonella spp. in ground beef packed by three commercially used packaging techniques. International Journal of Food Microbiology, 59, 211-220.

Nychas, G. J. E., Drosinos, E., \& Board, R. G. (1998). Chemical changes in stored meat In R. G. Board, \& A. R. Davies (Eds.), The microbiology of meat and poultry (pp. 288-326). London: Blackie Academic and Professional.

Phillips, C. A. (1996). Review: modified atmosphere packaging and its effects on the microbiological quality and safety produce. International Journal of Food Science \& Technology, 31, 463-479.

Pradhan, A. K., Li, M., Li, Y., Kelso, L. C., Costello, T. A., \& Johnson, M. G. (2012). A modified Weibull model for growth and survival of Listeria innocua and Salmonella Typhimurium in chicken breasts during refrigerated and frozen storage. Poultry Science, 91, 1482-1488.

Santos, M., Correia, C., Cunha, M., Saraiva, M., \& Novais, M. (2005). Valores Guia para avaliação da qualidade microbiológica de alimentos prontos a comer preparados em estabelecimentos de restauração. Revista da Ordem dos Farmacêuticos 64, 66-68.

Sheridan, J. J. Doherty, A., Allen, P. McDowell, D. A., Blair, L. S., \& Harrington, D. (1995). Investigations on the growth of Listeria monocytogenes on lamb under modified atmospheres. Food Microbiology, 12, 259-266.

Sofos, J. N., \& Geornaras, I. (2010). Overview of current meat hygiene and safety risks and summary of recent studies on biofilms, and control of Escherichia coli 0157:H7 in nonintact, and Listeria monocytogenes in ready-to-eat, meat products. Meat Science, 86, 2-14.

Stanbridge, L. H., \& Davies, A. R. (1998). The microbiology of chill-stored meat. In R. G. Board, \& A. R. Davies (Eds.), The microbiology of meat and poultry (pp. 174-219). London: Blackie Academic and Professional.

Swaminathan, B., \& Gerner-smidt, P. (2007). The epidemiology of human listeriosis Microbes and Infection, 9, 1236-1243.

Tsigarida, E., Skandamis, P., \& Nychas, G. J. E. (2000). Behaviour of Listeria monocytogenes and autochthonous flora on meat stored under aerobic, vaccum and modified atmosphere packaging conditions with or without the presence of oregano essential oil at $5{ }^{\circ}$ C. Journal of Applied Microbiology, 89, 901-909.

Uppal, K. K., Getty, K. J. K., Boyle, E. A. E., Harper, N. M., Lobaton-Sulabo, A. S. S., \& 
Barry, B. (2012). Effect of packaging and storage time on survival of Listeria monocytogenes on kippered beef steak and turkey tenders. Journal of Food Science, 71, 57-60.

Van Boekel, M. A. J. S. (2002). On the use of the Weibull model to describe therma inactivation of microbial vegetative cells. International Journal of Food Microbiology, 74, 139-159.
Xavier, C., Gonzales-Barron, U., Paula, V., Estevinho, L., \& Cadavez, V. (2014). Metaanalysis of the incidence of food-borne pathogens in Portuguese meats and their products. Food Research International, 55, 311-323.

Zakrys, P. I., Hogan, S. A., O'Sullivan, M. G., Allen, P., \& Kerry, J. P. (2008). Effects of oxygen concentration on the sensory evaluation and quality indicators of beef muscle packed under modified atmosphere. Meat Science, 79, 648-655. 